\title{
Cerca Trova: the Italian mafia on Dutch territory
}

\author{
Toine Spapens ${ }^{1}$
}

\section{Introduction}

An important perceived threat of transnational organised crime is that wellorganised networks spread their wings across the globe (e.g. Williams, 1994; Castells, 2000; Shelley et al., 2003; UNODC, 2010). In the Netherlands, these concerns focus particularly on the Italian mafia - here defined as the Cosa Nostra, 'Ndrangheta, Camorra and Sacra Corona Unita (SCU). Concerns were prompted by several indications. The Netherlands - together with Spain and Belgium - emerges from threat assessments as a European hub for shipments of cocaine coming in from South America and destined for Italy and the Dutch police also apprehend a relatively large number of mafia fugitives (Europol, 2017; Sarno, 2014). In 2011, the Dutch police studied the 'Ndrangheta's activities on Dutch territory and concluded that it represented a threat to the Netherlands (KLPD, 2011). Apart from that, the Italian mafia excites the imagination of many people and also piqued the interest of several Dutch enforcement officers. They were personally convinced that the Netherlands were attractive for these 'top dogs' of organised crime to open subdivisions, and lobbied their superiors intensively for the chance to delve deeper into the issue.

In 2012, the Minister of Justice and Safety commissioned a project aimed at establishing the level of subversive activities of the Italian mafia in the Netherlands. ${ }^{2}$ The project was named Cerca Trova, which translates

The author is Professor of criminology at Tilburg University, The Netherlands

2 In the Netherlands, serious and organised crime is now referred to as 'ondermijnende criminaliteit', which would translate into English as 'undermining', 'subversive' or 'disruptive' crime, though none of these terms is exact. Generally, it points to illegal activities that disrupt the integrity of economic life and of financial and governing institutions, but it may also refer to degradation of 
from Italian as 'seek and you will find', and ran from August 2012 to December 2015. This chapter will present an overview of the main outcomes of the Cerca Trova project in which the author participated as an external advisor. I will take the opportunity to discuss these results in the broader context of the debate on globalisation of organised crime. The next section starts with a brief overview of this discussion. Then, I will describe the methodology applied by the Cerca Trova project, as well as its general and specific outcomes. The latter refers to drug trafficking; violent crime; property crime; investment in and misuse of legitimate activities; and the topic of mafia fugitives in the Netherlands, although it must be noted that hiding to escape prison is technically not a crime. I will also address the Italian mafia's activities in the former Netherlands Antilles, although the Cerca Trova project itself was limited to the mainland Netherlands.

\section{Globalisation of organised crime: the debate}

\section{Globalisation and the fear of transnational organised crime}

Globalisation is a process that can be defined as the intensification of economic, political, social and cultural relations across borders (Holm and Sorensen, 1995). Since the early 1970s, globalisation has been considered a driver of prosperity, particularly in developing countries, but also a challenge, for instance for regulators, or even a threat, for example in the shape of uncontrolled migration from the global south to the global north (IMF, 2008; Braithwaite and Drahos, 2000). Particularly since the early 1990s, globalisation has accelerated because of market liberalisation and the lowering of trade barriers, but also because of increased mobility and cheap travel, as well as rapid developments in information and communication technology, including the emergence of the Internet.

Although globalisation has been approached predominantly from a perspective of global markets, others have focused on the role of transnational

the environment and societal values. Although the term is most commonly used in the context of serious and organised crime, it also applies to corporate crime. 
corporations. Scholars have also studied globalisation by looking at international networks of both large and small companies (Castells, 1996). From an international business perspective, multinational enterprises are considered a main agent of global integration, playing a pivotal role in linking rich and poor economies, and in transmitting capital, knowledge, ideas and value systems across borders (Meyer, 2004). However, others emphasise that multinational enterprises are also responsible for annihilating local firms; privatising resources such as drinking water; skimming off public funds through tax avoidance; and speeding up the degradation of the environment, which effects are particularly visible in the global south (Barber, 1996; Carrington et al., 2018).

Since the 1960s, organised crime researchers have often approached the provision of illegal goods and services from an economic perspective, both in terms of markets and logistics (e.g. Schelling 1965; Becker, 1968; Sieber and Bögel, 1993). Such approaches often result in transposing developments in legitimate economies to the criminal underworld and, not surprisingly, this also happened with the concept of globalisation. At the end of the 1980s, fear of an increase in transnational crime was also fuelled by the fall of the Iron Curtain and the subsequent implosion of the Soviet Union (Van Duyne, 1996; Hignett, 2004). Furthermore, developments in information and communication technology were expected to create new criminal opportunities and lead to the modernisation of existing illegal markets.

Next, investigative journalists and former members of the enforcement community started to compare transnational criminal organisations with multinational enterprises in books with appealing titles such as 'Octopus' (Sterling, 1990), 'McMafia' (Glenny, 2009), and 'Mafia Export' (Forgione, 2010). These books painted a picture of syndicates such as the Italian mafia, the Russian 'Mafiya', Chinese Triads and the Albanian mafia mimicking the behaviour of transnational corporations and setting up shops all over the world. From this perspective, mafias were compared to 'invasive exotics', because their level of organisational effectiveness, their methods of violence and corruption, as well as their expertise at hiding illegal activities could not be matched by indigenous criminal groups, or countered by local enforcement authorities. From an academic perspective, 'global crime' is more commonly approached in terms of networks and it is assumed that transnational organised crime groups, and particularly mafias, have increasingly forged worldwide alliances (Raine and Cilluffo, 
1994; Castells, 2000). These criminal networks are assumed to be highly flexible and able to move easily to other geographical areas and set up activities wherever it is convenient (Williams, 2001; Shelley, 2005).

Fear of transnational organised crime has sparked a range of responses, of which at the global level, the United Nations Convention against Transnational Organised Crime and the protocols thereto, which opened for signature in 2000 , is a notable example. However, organised crime researchers have also been critical of the picture of organised crime spreading across the world (e.g. Van Duyne, 1996; Van Duyne and Nelemans, 2011; Campana, 2011; Varese, 2011; Van Dijk and Spapens, 2014). I will address these views below.

\section{A critical view on transnational organised crime from a market perspective}

Critiques of warnings that crime markets are internationalising can be summarised as 'what is new'? It can indeed be argued that, for instance, trafficking of illegal substances, weapons, humans and non-human animals, as well as piracy and terrorism, have been going on for decades or even centuries (Reichel and Albanese, 2014). The same applies to transnational property crime and fraud, which were topics for Interpol already in the 1920s and 1930s (Bresler, 1992). In his memoirs, Dutch police commissioner Kallenborn, for example, describes a case of jewellery thieves in the 1920s who travelled across Europe to commit heists (Kallenborn, 1953). The notorious 'Pink Panther' gang, which originated from Serbia and robbed jewellery stores in Europe, Dubai and Japan between the mid-1990s and 2010, does not differ essentially from bands of international thieves operating as far back as the $17^{\text {th }}$ and $18^{\text {th }}$ centuries (Tremlett, 2010; Egmond, 2004). The only major difference in terms of crossing borders is means of transport and speed of travel. In addition, it is almost impossible to identify modern transnational crimes that did not already exist in some form in the past (Reichel and Albanese, 2014). Even cybercrimes can mostly be considered updated methods for committing theft, fraud or extortion. Hacking someone's online game to steal a valuable virtual sword may perhaps not have been possible without the Internet and computers, but in the end it is simply a theft, which probably causes similar harm to a victim as stealing his watch. 
What has changed, however, is the scale and diversity of transnational illegal markets (Dandurand et al., 1998; Reichel and Albanese, 2014). For example, thresholds for entering an illegal activity have been lowered. A person who is interested in producing some type of synthetic drug may nowadays order quantities of chemicals online, either on the open web or on the 'dark' web, and receive these by postal package. 'Silk road' was an example of a hidden website where users could order all sorts of narcotic drugs (Shelley and Hirst, 2017). Illegal online gambling is now estimated to be one of the most lucrative black markets (Havocscope, 2018). In the 1970 s, it would probably have been a local drug addict who stole your car radio, but nowadays the perpetrator may have come from anywhere in the world. Recently in the Netherlands, the police even apprehended a group of criminals who had flown in from Chile for the sole purpose of committing burglaries (Voskuil, 2018). Increased economic prosperity in, for example, Asia also led to growing demand for protected wildlife products, such as ivory (as a status symbol), and plants and animal products (for use in traditional medicine), with disastrous effects on populations of endangered species not only in Asia itself, but also in Africa and South America (Van Uhm, 2016).

Concerns about the consequences of the fall of the Iron Curtain proved to be generally correct, although these effects were sometimes temporary and certainly not as apocalyptic as some expected. In fact, the whole of Eastern Europe certainly did not develop into a hotbed of organised crime. But nevertheless, types of crime and victims, hardly occurring before, emerged at various spots: some temporarily others more permanent. Hungarian, Romanian and Bulgarian women do represent a substantial percentage of victims of exploitation as prostitutes in Western European countries (Nationaal Rapporteur, 2014; UNODC, 2016). In the 1990s, substantial quantities of small arms and light weapons leaked from stockpiles in former Soviet and Yugoslavian states. Arms traffickers such as Viktor Bout shipped large numbers of military weapons to conflict zones, mainly in Africa (Farah and Braun, 2006). Handguns, but also automatic weapons and explosives stemming from the Balkans and other Eastern European countries, ended up in the hands of criminals and terrorists in Western Europe (Duquet and Goris, 2018). It is also clear that itinerant gangs from 
Eastern and South-Eastern Europe seized the opportunity to commit property crimes in the West, and such groups are still active today (Spapens, 2008; Van Gestel, 2014).

\section{A critical view on transnational crime from the perspective of criminal organisations}

Criminologists have generally been far more critical of the idea that globalisation would enable criminal organisations to develop into multinational enterprises. Firstly, organised crime trading may be highly international, but it is also firmly embedded locally (Hobbs, 1998; Varese, 2011; Von Lampe, 2016). This is even more the case for mafia-type organisations than for trafficking networks (Gambetta, 1993; Chu, 2000). A criminal group that wants to establish a subdivision abroad must therefore be able to deal with circumstances that may be very different from those at home.

Secondly, practitioners and academics disagree about the level of organisation of mafias, especially on the question whether single groups or clans are governed by some overarching body and thus operate as a coordinated entity that would resemble a national or transnational corporation. When we look at the Italian mafia, for example, investigative journalists and current and former law enforcement officials mostly assume that such ruling bodies exist: the Cosa Nostra's two Cupola and the 'Ndrangheta's Crimine or Provincia. However, academics do not agree that these represent some form of higher management (e.g. Paoli, 2014). For example, the Camorra and SCU do not have comparable Commissions; the Cupola were established only in the 1950s and the Crimine not even before the 1990s (Dickie, 2013; Sciarrone, 2014). The Cosa Nostra's Cupola were established upon American advice mainly because the heroin trade required financial investments which were beyond the reach of a single clan (Dickie, 2013). Later, their main function was to prevent or solve violent conflicts between the clans, which sometimes caused hundreds of deaths. Indeed, such internal wars do not as such support the image of a well-managed syndicate.

Of course, examples of mafia groups establishing themselves on foreign territory did and still do exist, but without exception these concern single clans and individual members, and proof that a 'top management' is steer- 
ing global expansion is missing (e.g. Campana, 2011). Furthermore, Varese (2011) concludes that criminals move to another country not because of choice but because of necessity, for instance because they were forced to leave their country of origin which because of police attention or fellow criminals had become a too hot place. In practice, when foreign crime groups develop illegal activities on foreign territory voluntarily, we can observe two basic mechanisms. The first is through immigrant communities; the second is through affiliation with indigenous criminal groups. In practice, these mechanisms are often entwined to some extent.

Germany, Canada and Australia, for example, have substantial immigrant communities stemming from Calabria and indications exist that this allowed 'Ndrangheta clans to establish cells ("ndrine) there (Forgione, 2010; Gratteri and Nicasso, 2007). Mafia members extort the locals and may force them to support other illegal activities, for instance by making available housing and transport, often under threat of retribution against family members who reside in the country of origin. Comparable methods can be observed, for example, within Albanian and Chinese immigrant communities in Belgium and the Netherlands, respectively (Farcy 2002; Spapens 2008). However, 'outsiders' are usually not targeted for extortion because they cannot be intimidated in similar ways.

Thirdly, instead of battling indigenous crime groups for territories or markets, it will usually be more lucrative for foreign groups to seek cooperation. Alliances may be ad-hoc, for instance to organise a shipment of illicit goods, but may develop further over time. An example is synthetic drugs production in the Dutch-Belgian border area. Here, Dutch criminal groups started to set up laboratories from the beginning of the 1990s onwards (Van Duyne, 1995). These activities were established in cooperation with Belgians, although in most cases they were led by Dutch criminals, but gradually an integrated criminal network emerged (Spapens, 2006; 2008; Colman et al., 2018).

The idea of foreign criminal groups as 'invasive exotics' can also be challenged. The main assumptions seem to be that newcomers are more violent and better at hiding their activities, which gives them the advantage over indigenous criminals and law enforcement. However, applying violence is not the smartest thing to do and there seems to be little reason why local criminals should not quickly be able to match foreign groups in this respect (Van Dijk and Spapens, 2014). Secondly, newcomers may instead 
be even less effective in screening off their activities in a new environment, for instance when they are unfamiliar with local law enforcement tactics. In the 1990s, for example, American buyers who were sent to the Netherlands to acquire large quantities of ecstasy pills were not accustomed to the Dutch police's extensive wiretapping and, despite ample warnings from their Dutch suppliers, they persisted in talking too much over the phone (Spapens, 2006).

If foreign criminal groups establish themselves in countries where law enforcement is weak, the situation may, however, be different. An example is the Mara Salvatrucha or MS-13 gang, which was originally formed by El Salvadorian youths in Los Angeles in the 1980s. Large numbers of its members were expelled to El Salvador - for the moment I will leave aside that because of this they were technically not foreigners - and continued with criminal activities there, to which the government, weakened by civil war, was unable to respond effectively (Malone and Malone-Rowe, 2014). Furthermore, MS-13 also established itself in other Central American countries, such as Honduras and Guatemala, whilst retaining a strong presence in the United States.

Outlaw motorcycle gangs might be brought up as another example of syndicates that succeed in setting up chapters in different parts of the world. However, these chapters are mostly composed of local members who are not under foreign leadership. It is unclear to what extent such chapters are directly 'managed' from abroad or remain instead relatively independent in choosing their criminal and other activities. The latter option seems to be more realistic (UNODC, 2002). Furthermore, OMCG chapters may be heavily involved in crime, but they are also highly visible. All in all, these gangs do not seem to qualify very well as invasive exotics who may someday succeed in replacing local criminals.

In conclusion, globalisation has obviously increased opportunities for transnational organised crime on the one hand, but on the other, we must not forget that especially mafia-type illegal activities, such as protection/extortion and collusion with authorities to acquire public funds, are deeply embedded in local settings. In the remainder of this paper, I will look at activities of Italian organised crime in the Netherlands and then reflect on these findings from the perspectives described above. The next section first discusses data collection. 


\section{Cerca Trova: data collection and analysis}

Cerca Trova operated as a joint team composed of staff of the Dutch police, the tax authorities, the Fiscal Intelligence and Investigation Service (FIOD), and the Public Prosecution Service. It consisted of practitioners, i.e. experienced detectives, intelligence analysts of different agencies, students at the police academy who did research for the team in the context of their bachelor thesis, and a public prosecutor. Several members of the team were fluent in Italian, and some already held extensive knowledge about the Italian mafia out of personal interest. The present author was attached to the project to provide advice and safeguard scientific quality and edited the final report (Cerca Trova, 2017).

The aim of the project was first to produce a reliable intelligence picture, which was to be made available to the Dutch Parliament in an anonymised and public format. Second, the team was to support regular investigative work related to Italian organised crime. In practice, this meant that team members acted as intermediaries between Italian and Dutch enforcement agencies in ongoing cross-border cases, and provided information to regular Dutch police investigation teams for further consideration.

The team relied for the most part on information available from the Dutch police and the judiciary, the Tax Administration and administrative agencies, as well as on information coming from Italy in letters rogatory. Team members also collected open source information and conducted interviews with practitioners in the Netherlands, Belgium, Germany and Italy, as well as with five academic researchers of Italian organised crime. Cerca Trova's preliminary findings were presented to, and discussed with, Italian law enforcement officials during visits to Rome and Reggio Calabria in January 2015.

Data collection resulted in a database of 276 mafia-related crime cases which were investigated from 1989 to 2014 . Most cases were initially retrieved from a database of requests for mutual legal assistance kept by the Dutch police liaison post in Rome, to which information was added from case files and intelligence sources; interviews with detectives who were involved (if necessary); and open sources. 


\section{a. The past and present of Italian mafia activities in the Netherlands}

The presence of the Italian mafia in the Netherlands has been documented since the 1970s. At that time, the Camorra, for example, acquired illegal cigarettes in Rotterdam, which were smuggled to, and sold in, Italy (Arlacchi, 1993, p. 123). In 1992, the Dutch police analysed 30 investigation cases related to Italy which mainly concerned cocaine trafficking, but also money laundering, murder and small-scale arms trafficking (CRI, 1992). Mafia-affiliated individuals had started Italian restaurants as early as in the 1980s and these establishments became meeting places for members of the Italian criminal underworld who visited the Netherlands, whilst some owners were themselves actively involved in the drug trade. The police observed links with several clans of the Camorra, such as the Annunziata, the La Torre and the Stolder clans, whereas other restaurant owners could also be linked to the Cosa Nostra (CRI, 1992).

In 1995, a research group drew a picture of organised crime in the Netherlands in the context of a parliamentary enquiry (Tweede Kamer, 1995). Information on the Italian mafia, however, was scarce, because only one substantial investigation had been completed since 1992. This operation, codenamed Campina (Camorra-Pizzeria-Naples), had confirmed earlier findings that the Camorra was involved in trafficking cocaine from the Netherlands to Italy. Camorra representatives bought the drugs on behalf of different clans, and sometimes for other mafia groups as well. Small and medium-sized shipments were transported by road with couriers, sometimes hidden between flowers, whereas larger shipments were allegedly sent to Southern Italy by ship. Mafia members met in Italian restaurants with Colombian, Turkish, Surinamese and Netherlands-Antillean drug suppliers (Tweede Kamer, 1995). However, the research group found no indications that Italian organised crime had managed to set up a permanent bridgehead in the Netherlands. In 2001, the police updated its 1992 analysis, but this brought no additional insights. Almost 10 years later, the police published a new report which focused specifically on the "Ndrangheta (KLPD, 2011). This report was again based on police information, but also on a substantial number of interviews with Italian and other enforcement representatives. As mentioned above, the Cerca Trova project was the most 
recent effort to draw a picture of the Italian mafia's activities on Dutch territory.

The Cerca Trova team compiled a database spanning a period of 25 years, and Table 1 presents an overview of the type of activities mentioned in these files for mutual legal assistance. In total, 461 different illegal activities were mentioned. Almost $60 \%$ of mafia-related activities concerned different types of narcotic drugs, mostly cocaine. Remarkably, only $2 \%$ of the cases involved synthetic drugs, although the Netherlands are viewed as a main producer of ecstasy and amphetamine (Tops et al., 2018). Other activities mentioned relatively often are money laundering and the hiding of mafia members from the Italian authorities in the Netherlands.

Table 1

Illegal activities mentioned in requests for mutual legal assistance (1989-2014)

\begin{tabular}{|l|l|l|}
\hline Illegal activity & Number & \% \\
\hline Cocaine & 131 & 28 \\
\hline Cannabis and hashish & 34 & 7 \\
\hline Heroin & 3 & 1 \\
\hline Synthetic drugs & 10 & 2 \\
\hline Narcotic drugs unspecified & 113 & 25 \\
\hline Money laundering & 40 & 9 \\
\hline Mafia fugitives & 37 & 8 \\
\hline Violent crimes/murder/firearms & 14 & 3 \\
\hline Fraud & 12 & 3 \\
\hline Extortion & 9 & 2 \\
\hline Other & 27 & 6 \\
\hline Unknown & 31 & 7 \\
\hline Total & $\mathbf{4 6 1}$ & $\mathbf{1 0 0}$ \\
\hline
\end{tabular}

Although the cases are mafia-related, only $68 \%$ of the subjects mentioned held either Italian or Dutch nationality (both 34\%). Italian-Dutch criminal cooperation which involves mafia members is more international than that. German, Spanish, Belgian and Colombian nationals account for another $14 \%$. In total, 61 different nationalities were mentioned in the case files, showing the interconnectedness of transnational criminal networks. The next sections address the main types of illegal activities. 


\section{b. Drug trafficking}

The database shows that Camorra and "Ndrangheta are prominent in the context of drug trafficking. They account for $90 \%$ of the cases in which a specific mafia was mentioned. By comparison, the roles of Cosa Nostra (4\%) and Sacra Corona Unita (6\%) are modest. In half and a third of the cases, respectively, Cosa Nostra and SCU cooperated with the Camorra. Cooperation between Camorra and 'Ndrangheta is less common, and was observed in only 6 cases. Earlier research showed that different clans invest together in drug shipments and Cerca Trova again confirmed this (Tweede Kamer, 1995; KLPD, 2011). Available information shows that the Netherlands is not the territory of specific clans.

The Netherlands and Spain are the main European ports of entry for cocaine (Europol, 2013). The case files did not reveal why Italian mafias use the Netherlands (and Spain) for this purpose and do not ship cocaine directly from South America to Italy. According to Italian law enforcement officers, this could be explained by the fact that ports in Italy are under much stronger surveillance than the Dutch and Spanish harbours. This explanation is not very convincing, however, because the long Italian coastline presents ample opportunity to circumvent ports altogether and pick up and deliver shipments with small motorboats, for example. Occasionally, cocaine shipments are indeed intercepted in Italy, for instance in 2010 when police seized 1.000 kilos in a Calabrian port. Strangely, the press reported that the shipment was destined for the Netherlands and the United Kingdom instead of Italy (De Gelderlander, 2010). However, in almost all cases the cocaine shipped through the Netherlands was destined for Italy.

Mafia-affiliated Italian immigrants and fugitives who hide in the Netherlands play an important role in maintaining contacts with Dutch criminal groups. It is unknown whether Dutch criminals were solely hired to take care of shipments, or invested in cocaine together with the mafia and other groups. Dutch criminals know their way around the ports and possibly also maintain contacts with corrupt Customs officials. Several cases of corruption in the port of Rotterdam have come to light in recent years (Rovers, 2018).

Police observations of meetings suggest that the mafia also does business directly with Colombian suppliers. These meetings may concern incoming shipments, but it is also possible that business relations have 
evolved to the extent that orders can be placed directly with representatives of cocaine producers who reside in the Netherlands and no longer require to visit to Colombia. In the few cases in which the mafia seemed to operate independently from Dutch criminals, Albanians and Romanians removed the drugs from containers that had arrived in the port of Rotterdam, whilst mafia members monitored the operation from a distance. Entering container terminals illegally by simply climbing over a fence and removing packets of drugs from containers before they go through customs is a rather crude method. The risk of getting caught is substantial, because entry to these terminals is guarded with fences, cameras and other detection equipment, which seems to suggest that cooperation with Dutch criminals who do not need to apply such cowboy methods is indeed a safer bet.

Drugs that have entered the Netherlands are usually forwarded to Italy by road, either by couriers in private vehicles or hidden between truckloads of regular goods such as flowers and fruit. Because of the abolition of fixed border controls in the Schengen area - most of the European mainland traffickers do not need to take extensive measures to conceal illicit goods, because the risk of being stopped and searched is almost zero if one drives carefully and avoids weekend nights (Spapens, 2008). Individual shipments tend to be relatively small, often just a few up to several tens of kilos, and can easily be hidden in empty spaces in private cars, for example in the doors.

Couriers, usually young males who reside in Italy but hold all sorts of nationalities, receive an airline ticket to the Netherlands and some pocket money to enjoy a few days of leisure, and are then tasked with driving a car back in which drugs are hidden. Smuggling drugs between flowers is also an effective method because flowers are distributed to even the smallest villages. The police are aware of this method, but they will only stop and search a transport when they are certain that the cargo contains drugs, because flowers are both valuable and vulnerable and if nothing illegal is found, the authorities will face substantial claims for damages.

\section{c. Violent crime on Dutch territory}

Italian organised crime is reputed for its violence. Cerca Trova, therefore, expected that mafia presence on Dutch territory would be visible in under- 
world killings. Between 1988 and 2014, 13 persons were the victim of mafia-initiated murders, including one case in which the Dutch police intervened and prevented the killing. ${ }^{3}$ In addition, Cerca Trova identified four possible murders, three of which were mentioned by crown witnesses in statements but could not be confirmed because no bodies were ever found. The fourth case concerned the suicide of a Camorra fugitive in which there were indications that he was in fact murdered. Except in two cases, all actual or possible murders were committed before 2002, especially by the SCU (six, possibly eight) and the Camorra (five, all before 1992). Most killings were drug-related, or appeared to be, for instance because subsequent investigation pointed to business conflicts related to drugs or theft ('ripping') of drugs.

Acts of punishment could rarely be identified, because in a relatively large number of cases, the police were unable to collect sufficient evidence to allow a conviction, and in some cases, perpetrators managed to escape long prison terms by becoming a collaboratore di giustizia, the most notable example being Filippo Cerfeda, a SCU member who killed four people in the Netherlands. Giorgio Basile, another pentito, also confessed to an unknown murder (Ulrich, 2005).

All in all, the level of mafia violence on Dutch territory is rather limited and almost no killings have taken place in the past 16 years, which seems to underline that its members prefer to stay under the radar and avoid attracting attention to the drug trade. The fact that the SCU was held responsible for most killings is also an indication of unplanned violence because its members have a reputation for lack of discipline (Massari, 2014).

Some members of the Cerca Trova team assumed that the mafia has simply become better in hiding its murders, for instance by disguising them as suicides or by employing non-Italian killers. However, looking into several potentially suspicious killings which involved suspects or victims of Italian nationality or descent did not produce any connections with mafia clans. On the one hand, this still does not rule out that the mafia ordered murders of non-Italians and hired non-Italians to commit them. On the

3 In 2017, after Cerca Trova was finished, one more mafia murder was committed, which could be attributed to a conflict in Italy. The victim had unsuccessfully sought refuge in the Netherlands. 
other hand, underworld killings are often also meant as a message and it will be at least partly ineffective if no one knows who sent it.

\section{d. Property crimes}

In Italy, the mafia is well-known for committing property crimes. Extortion of legitimate businesses is generally seen as a classic mafia-style crime, but its members are also involved in other types of property crimes. The Cerca Trova database contained 28 examples of property crimes, with fraud (12) and extortion (9) being the largest categories.

At first glance, extortion seems to be a relatively large category, but in fact none of these cases took place on Dutch territory. All but one concerned investigations of extortion committed in Italy by mafia members who had fled to or took up residence in the Netherlands. The remaining case involved a restaurant owner who was also a drug dealer and the police established that extortion had in fact been a financial conflict with a SCU member because of a failed transaction.

In the 1990s, there had been indications that the mafia extorted Italian restaurants in the Netherlands, but these had been too vague to lead to further investigation. Cerca Trova did not find or receive more recent signals of mafia-related extortion. It must be noted that this type of crime is difficult to detect because the victims are often reluctant to report it to the police. The team therefore looked at cases in which Italian restaurants or businesses owned by Italian nationals became the victim of inexplicable violence or arson, which might indicate an unwillingness to pay protection money or refusal to buy specific ingredients from 'designated' companies in Italy. The Bundeskriminalamt had observed the latter in investigations in Germany. However, this rendered only one case in which a recently opened restaurant was severely damaged for no apparent reason, but mafia involvement could not be established. In 2017, the Dutch police issued a press release about another case in which two restaurants were attacked, after which an Italian national was arrested in Spain, but again no mafia affiliation was mentioned (Nationale politie, 2017).

In 2016, a major criminal investigation in the Netherlands made clear that the brothers Vincenzo and Giuseppe Crupi, who the Italian police saw as members of the 'Ndrangheta's Commisso clan, controlled a Dutch flower export company. The Dutch police assumed that this company was 
originally established for trafficking drugs, but that the owners had now also expanded to a range of property crimes (Anesi et al, 2017; De Jong and Voskuil, 2017). The most important of these was long firm fraud: the company ordered large quantities of flowers from Dutch suppliers but failed to pay the bills. Several suppliers went bankrupt as a result, and representatives who called for payment received serious verbal threats, although this did not scare them from reporting to the police. In addition, the investigation also linked suspects to bankruptcy fraud and VAT fraud, as well as to the fencing of expensive Swiss chocolate. The case also led to a large-scale investigation in Calabria and the Italian authorities seized assets to the value of $€ 30$ million. In Italy, the clan had invested money in 13 flower companies, 21 stores, 22 apartments and two hotels (De Jong and Voskuil 2017). The 'Ndrangheta is allegedly still active in the Dutch flower trade: another person originating from Calabria started a new business and employs most of the former staff of the mafia-controlled company (De Jong and Voskuil, 2017). However, new instances of fraud involving this company have so far not been reported, although flower traders must remain highly alert for Italian buyers who never pay their bills.

\section{e. Investments in and misuse of legitimate businesses}

The flower trade is one trade sector in which Italian organised crime invested in the Netherlands. Another sector that appeared to be vulnerable is the Italian catering sector. Analyses indicated that 22 Italian restaurants might be associated with the mafia (out of 1.205 venues). The project team was unable to determine whether the venues were specifically set up by the Italian mafia to facilitate criminal activities in the Netherlands or instead to launder money. In three cases, existing or former restaurant owners were convicted of mafia membership in Italy; in eight cases, police information showed that mafia members used the venue as a meeting place; and in a further eight cases, officers observed contacts between the owner and known mafia members. The remaining restaurant owners were suspected of involvement in serious or organised crime and the venues were frequented by criminals active in the drug trade, but no direct mafia links could be established.

Analysis also showed no indications of large-scale mafia-initiated investments or fraud schemes in other economic sectors in the Netherlands. 274 
However, there were at the time several cases under investigation in which the Italian mafia was suspected of having used Dutch companies and financial service providers as intermediaries to move capital to and from Italy. The Netherlands has many Trust Offices (legal entities, partnerships or natural persons that provide one or more trust services on a commercial basis), which are vulnerable to being misused for this purpose. In one case under investigation, capital originating from different countries was invested in companies that wanted to buy real estate the Italian authorities had earlier seized from the mafia. Dutch legal persons represented by a Trust Office in Amsterdam participated in these companies to the value of $€ 2$ billion. This and a few other, similar, cases are still under investigation in the Netherlands and Italy, but at the time of writing, enforcement agencies had not been able to produce concrete evidence of mafia-related money laundering.

In Italy, the mafia is known to be involved in procuring government contracts, particularly for construction work in which mafia-controlled companies can acquire contracts via corrupt local or other officials. To curb this problem, the Italian authorities have implemented anti-mafia legislation that includes thorough screening of any private company that wants to work for the government or apply for a subsidy. Setting up a company in another EU Member State may make it possible to circumvent these background checks. Within the current legal framework, it is difficult to exchange police intelligence, on which effective screening often depends, for purposes other than criminal investigation; but this case concerned administrative screening (Spapens et al., 2015). In one concrete example, the Italian authorities requested background information on a Dutch company that was hired to do installation work at the Milan Expo, but this was refused by the Dutch public prosecution service because of a lack of clarity regarding the legal provisions for mutual assistance in criminal matters (Spapens et al., 2015). Although this situation presents a loophole to criminals, Cerca Trova did not find examples of Dutch companies that might have been set up to avoid anti-mafia background checks in Italy.

\section{f. The Netherlands as a hiding place for mafia fugitives}

Finally, the Cerca Trova project looked at mafia fugitives who use the Netherlands as a hiding place. Over the years, a relatively large number of 
wanted mafia members have been apprehended in the Netherlands. Between 1992 and 2014, the Dutch authorities arrested 55 mafia members who had been living there for shorter or longer periods. The Italian authorities provided information on a further 38 individuals who could not be traced in time. Most fugitives were members of the 'Ndrangheta and Camorra. Cosa Nostra members are relatively rare. According to Italian enforcement officers we interviewed, they usually choose to hide in Sicily. Fugitives do not belong to specific clans, although a relatively large number were members of the Calabrian Strangio-Nirta clan.

The media usually refer to apprehended mafia members as kingpins but in fact they are mostly lower to middle-ranking within their clans. The leaders prefer to stick close to their territory in Italy. Although the relative number of latitanti is higher than in all other European countries except for Spain, the Cerca Trova project was unable to establish with certainty why the Netherlands is attractive to mafia fugitives. Apprehended suspects logically provide no information on this. From interviews with enforcement officers, two potential explanations arise.

The first is that fugitives usually choose countries where they feel at home to some extent. Latitanti who went to the Netherlands had probably visited the country before and established contacts with persons who were willing to help them organise their stay, for instance by discreetly providing housing and a job. Apart from using a false identity, many took no specific precautions to avoid being found and worked, for instance in an Italian restaurant, or had their own business. Others received social benefits, one person even in his own name. Apparently, most fugitives felt completely safe, except for those who were hunted by rival clans. Although the Dutch weather is usually less attractive than that of Spain, for example, and cultural and language barriers may be greater, the country's international orientation, its excellent infrastructure and airline connections with Italy, as well as the fact that almost all Dutch think positively of Italian culture and lifestyle, were also thought to be reasons why mafia members favour the Netherlands (KLPD, 2011).

However, Italian police officers we interviewed largely dismissed those factors and stated that all North-Western European countries are similar in these respects. Instead, they pointed to a second explanation: the fact that in the Netherlands - as in Spain - fugitives can continue to play a useful 
role in drug trafficking operations. Several indications support this explanation. It was observed, for instance, that some mafia fugitives maintained contacts with South-American cocaine suppliers. Latitanti also supported mafia members who visited the Netherlands to negotiate drug deals, and assisted drug and money couriers who came to the country. In several cases, large sums of cash were found when the police apprehended a fugitive, much more than was necessary for covering the costs of living, and possibly intended for buying drugs.

\section{g. Mafia infiltration in the former Netherlands Antilles}

The Cerca Trova project was limited to the Netherlands itself, but the media have reported on several cases of mafia infiltration in what were then the Netherlands Antilles. These refer to the islands of Sint Maarten and Curaçao, which have held an independent status within the Kingdom of the Netherlands since 2010, although the judiciary and the police, for example, remain the responsibility of the Dutch authorities. It must be noted that Dutch legislation does not include provisions for convicting a person of mafia membership, and that all persons mentioned below have always denied being part of - or even affiliated with - the mafia.

On Sint Maarten, reports of mafia infiltration date from as early as the 1970s (De Jong and Voskuil, 2017). This started when Sicilian businessman Rosario Spadaro bought a hotel which he developed into a casino. Spadaro was linked to the Italian-American Cellini family, which participated in the illegal gambling operations of Meyer Lansky. Originally, one of the Cellinis co-owned the casino, but the Dutch authorities had refused him an operating licence. From unknown sources, Spadaro then raised money to buy out Cellini and gradually acquired a substantial number of properties and businesses on the island. Inevitably, warm contacts developed between Spadaro and local top politicians, culminating at the end of the 1980s in a joint venture for expanding the island's airport and harbour. Italian companies were hired to do the construction work, whilst Italian banks provided funding. Companies set up by Spadaro and his political friends inflated the costs of the projects by $€ 18,8$ million and in 1995, Spadaro was sentenced to 12 months' imprisonment for this fraud (De Jong and Voskuil, 2017). 
At the end of the 1970s, another Sicilian native named Gaetano Corallo also appeared on Sint Maarten to open a gaming house. He already owned several casinos in Italy and sought to expand his business to the Netherlands Antilles. In 1983, however, he was suspected of working for the Cosa Nostra's Santapaola clan and fled to Florida, where he was arrested and extradited to Italy in 1989. By that time, he had already entrusted his son Francesco with the Sint Maarten casino (De Jong and Voskuil, 2017). Over the following years, the younger Corallo acquired casinos in several countries, and he also became one of the largest operators of electronic gaming machines in Italy. He too developed close relations with politicians in the Netherlands Antilles, most noticeably Gerrit Schotte, who in 2010 became the first prime minister of (semi) independent Curaçao. Almost immediately after taking office, Schotte faced increasingly severe allegations of corruption. These also implicated Corallo, who was suspected of having financed Schotte in return for an important public position (GHJ, 2017).

The Dutch public prosecution service started an investigation and the Italian authorities provided information in which Corallo, although he had never been convicted, was identified as a mafia member and accused of being involved in drug trafficking and money laundering (De Jong and Voskuil, 2017). In August 2012, Corallo was put on Interpol's red notice list. In 2016, the court sentenced Schotte to three years' imprisonment for accepting bribes from Corallo, and the sentence was confirmed on appeal in July 2017 (GHJ, 2017). In December 2016, Dutch authorities arrested Corallo and, after having spent eight months in pre-trial detention, he was extradited to Italy on charges of large-scale tax evasion, money laundering and bribery, related to his gambling machines. However, the Italian judiciary apparently failed to build a credible case against him, because in Italy, Corallo's pre-trial detention was discontinued immediately upon his arrival. When his passport was also returned to him in July 2018, he returned to Sint Maarten, prompting quite a few raised eyebrows (Zwart, 2018; Antilliaans Dagblad, 2018). Dutch authorities had expected that Corallo would receive a long prison term in Italy, but must now decide whether to prosecute him for bribing Schotte. 


\section{Discussion and conclusion}

Based on the information available, Cerca Trova confirmed that the Italian mafia is indeed active on Dutch territory, particularly the "Ndrangheta and Camorra. Almost all activities are related to the drug trade, for which several clans have maintained a stable presence in the Netherlands since the 1980 s. Its members regularly visit the country to negotiate with drug suppliers and to organise shipments, or perform similar tasks while hiding from the Italian police or rival clans. The mafia has access to, or has established, a supporting infrastructure, for instance in the shape of restaurants where meetings can be organised safely, and companies in economic sectors that are useful for trafficking drugs, such as the flower trade. Individuals, Italian as well as Dutch nationals, provide assistance such as housing and transport.

However, there is always a risk that criminals who are present in a country for one reason seek to expand their business for their own reasons. The fact that 'Ndrangheta members thought it a good idea to start ordering flowers without paying for them illustrates this. Given the risks involved, it is hard to imagine that a sensible and well-organised crime syndicate managing things from Italy would have allowed them to do so, given the risk of detection.

Occurrences in the former Netherlands Antilles demonstrate the disruptive effect mafia infiltration may have when economies are weak and authorities lack integrity. Of course, any person who invests substantial sums in a local economy will rapidly build influence with politicians. If the latter are prone to corruption, the relationship may be misused to acquire government contracts or positions. Although this opens the way to classic mafia-type crimes, it does not necessarily require a mafia organisation; any white-collar criminal might do the same. Once again, we cannot assess whether, for instance, Francesco Corallo was under the direct control of Sicilian 'masters' or was operating independently.

In the Netherlands, the Italian mafia is not an 'invasive exotic'. It did not attempt to take over existing illegal markets or to open new ones. Instead, in the drug trade we mostly see close cooperation with Dutch and other criminals. Involvement in the flower trade and possibly the Italian catering branch did not spark conflict with the indigenous criminal underworld. 
A protective factor for the Netherlands seems to be the lack of a substantial Italian community originating from the southern part of Italy. Most Italian immigrants who came to the Netherlands after the First World War and have since acquired Dutch citizenship, come from the north of Italy. The number of Italian nationals is about 50.000 and thus rather small, and it is partly made up of students and others who reside in the Netherlands temporarily. There are no concentrations of Italians in specific neighbourhoods. This makes it much harder for the mafia to parasitize on their fellow countrymen than, for instance, in Germany, Canada and Australia - countries with relatively large and concentrated communities originating from southern Italy.

In the Netherlands, the Italian mafia has not introduced more effective or more violent methods of organised crime. Since 2002, the mafia has virtually refrained from openly committing murders on Dutch territory and indications of extortion-related violence and threats are almost non-existent. When it comes to applying methods to avoid detection and prevent enforcement agencies from acquiring evidence, the picture is rather mixed. The police did notice mafia members who were very apprehensive of being wiretapped and followed, and they also used false identities. However, Dutch criminals apply the same methods. Remarkably, other mafia members hardly took any precautions to avoid being identified, and some fugitives even used their real names. Furthermore, it only took a phone call to Italy to tie businessmen such as the Corallos and the Crupis to the mafia. Although they were running a legal business on paper, this does not seem to match the image of a highly professional criminal organisation trying to set up shop abroad and remain undetected.

It is important to discuss whether the available information indeed paints a reliable picture of the mafia's activities on Dutch territory. Within the Cerca Trova team, this question was from time to time fiercely debated. To begin with, a general weakness of information collected by law enforcement is that it mostly represents investigative priorities and does not necessarily provide insight into the full range of activities of the criminal underworld (Hobbs and Antonopoulos, 2014). Apart from that, police information may be flawed by practical issues. As mentioned above, most cases included in the Cerca Trova database had Italian letters rogatory as a starting point and these usually emphasise illegal activities which are known 
priorities in the requested country, to ensure maximum assistance. Therefore, property crimes and trafficking of marijuana, which hardly spur the Dutch public prosecutors into action, may have been mentioned less than, for instance, cocaine. In addition, crimes without a direct international link, such as extortion of local businesses, may not be visible at all in international assistance requests. Also, peculiarities of the Dutch Police Information Act (Wet Politiegegevens) made it difficult to obtain information older than five years, and if questions arose, it was sometimes problematic to find additional material regarding old cases. However, a more fundamental issue in organised crime research - or any study of an 'invisible' illegal activity - will always be to what extent missing information implies that no substantial problems exist, or instead that we are dealing with extremely smart criminals.

Some Cerca Trova team members held the latter opinion, which they underpinned, among other things, by pointing to statements delivered by collaboratore di giustizia such as Cerfeda and Basile about hitherto unknown crimes they had committed in the Netherlands. In addition, Italian police officers explained that in some cases, only far-reaching long-term investigations had supplied the necessary evidence, and that this had required, for instance, wiretapping of hundreds of subjects. According to them, it was particularly difficult to prove crimes of collusion, with Rome's mafia capitale case as an example. Of course, such efforts had been impossible in the context of Cerca Trova, and this deeply frustrated several team members who felt they had had no proper chance to uncover what was potentially hidden.

Others, including the author, took a more pragmatic approach. Although organised crime groups are sometimes compared to secret societies, it is very unlikely that they can keep their activities completely hidden, whilst at the same time exerting highly disruptive effects on society. It may be necessary to go to great lengths to acquire evidence to prove your case in court, but here we were only looking for indications of mafia activity. If the mafia had indeed infiltrated deeply into the Dutch economy, or had for decades systematically applied methods such as extortion, chances are slim that enforcement agencies would not have received any signal at all. In fact, intelligence on mafia activities in the Netherlands had been consistent since the 1990s. Infiltration of legitimate businesses and politics did indeed succeed in the former Netherlands Antilles, but this merely proves the 
point that politicians who are susceptible to corruption are vulnerable to any type of villain, mafia affiliated or otherwise. So far, we have no indications that in the Netherlands itself it is equally easy to find influential politicians who would not mind colluding with the mafia.

Regardless of how one views the question of whether Cerca Trova did or did not provide the full picture, the project made it clear that the Italian mafia's activities in the Netherlands should be monitored and disrupted where possible. As a follow-up, a small police team was established for this purpose.

In the context of the debate on globalisation of organised crime, we may conclude, however, that developments in the past three or four decades have not structurally changed the market for the Italian mafia in the Netherlands, and that the mafia has not managed to alter the indigenous Dutch criminal underworld or (even partly) replace it.

\section{References}

Anesi, C., G. Rubino and K. Voskuil, Maffia nog steeds actief op bloemenveiling. $A D, 27$ March 2017.

Antilliaans dagblad, 'Corallo wordt vrijgesproken', 5 August 2018.

Arlacchi, P., Leven in de mafia; Het verhaal van Antonino Calderone. Amsterdam, Nijgh en Van Ditmar, 1993.

Barber, B. Jihad vs McWorld. New York, Times Books, 1995.

Becker, G., Crime and punishment: An economic approach, Journal of Political Economy, Vol. 76, 1968, 169-217.

Braithwaite, D. and P. Drahos, Global business regulation. Cambridge, Cambridge University Press, 2000.

Bresler, F., Interpol. London, Sinclair-Stevenson Ltd, 1992.

Campana, P., Eavesdropping on the Mob: the functional diversification of Mafia activities across territories. European Journal of Criminology, 8 (3), 2011, 213-228.

Carrington, K., R. Hogg, J. Scott and M. Sozzo, (eds.), The Palgrave handbook of criminology and the Global South. Cham, Palgrave McMillan, 2018. 
Castells, M., The rise of the network society. Cambridge and Oxford, Blackwell, 1996.

Castells, M., The perverse connection: The global criminal economy. In: M. Castells, End of millennium, the information age: Economy, society and culture vol. III. Oxford, Blackwell Publishers, 2000.

Cerca Trova, Cerca Trova. Een analyse van de Italiaanse maffia in Nederland. The Hague, Ministerie van Justitie en Veiligheid, 2017.

Chu Y.K., The Triads as Business. London and New York, Routledge, 2000.

Colman, C., F. De Middeleer, T. Spapens, S. van Nimwegen, R. Ceulen, S Gerbrands, L. Paoli, E. Roevens, E., De grens voorbij? The Hague, Boom Criminologie, 2018.

CRI, Italiaanse Misdaadorganisaties in relatie tot Nederland. Zoetermeer, 1992.

Dandurand, Y. B. Tkachuk and A. Castle, Recent international efforts to address transnational crime. Paper presented at the International Conference on Crime and Criminal Justice in a Borderless Era, Kyoto, 2 November 1998.

De Gelderlander, Enorme drugsvangst in Italië, 15 November 2010.

Dickie, J., Mafia Republic. London, Hodder and Stoughton, 2013.

Duquet, N. and K. Goris, Firearms acquisition by terrorists in Europe. Research findings and policy recommendations of Project SAFTE. Brussels, Flemish Peace Institute, 2018.

Duyne, P.C. van, The phantom and threat of organised crime. Crime, Law and Social Change, 24, 1996, 341-377.

Duyne, P.C. van and M. Nelemans, Transnational organised crime: Thinking in and out of Plato's cave. In: F. Allum and S. Gilmour, Handbook of transnational crime. London: Routledge.

Dijk, J. van and T. Spapens, Transnational organized crime networks across the world. In: J. Albanese and P. Reichel, Transnational organized crime: An overview from six continents. Thousand Oaks, Sage, 2014.

Egmond, F., Multiple underworlds in the Dutch Republic of the Seventeenth and Eighteenth Centuries. In: C. Fijnaut and L. Paoli, Organised crime in Europe. Dordrecht, Springer, 2004, 77-107.

Europol, SOCTA 2013. Europol serious and organized crime threat assessment. The Hague, 2013. 
Europol, Serious and organised crime threat assessment 2017, The Hague, 2017.

Farah, D. and S. Braun, Merchant of death. New Jersey, Wiley, 2006.

Farcy, F., How is the Albanian Mafia setting up; locally, nationally and in Europe. Paris, Institut de criminologie. Département de recherche sur les menaces criminelles contemporaines, December 2002.

Forgione, F. Mafia export. Come 'Ndrangheta, Cosa Nostra e Camorra hanno colonizzato il mondo. Milan, Baldini Castoldi Dalai, 2010.

Gambetta, D., The Sicilian Mafia. Cambridge MA, Harvard University Press, 1993.

GHJ (Gemeenschappelijk Hof van Justitie van Aruba, Curaçao, Sint Maarten en van Bonaire, Sint Eustatius en Saba), Zaaknummer: H-38/16, strafvonnis. 21 July 2017.

Gestel, van, B., Facilitering van mobiele bendes. The Hague, WODC, 2014.

Glenny, M. McMafia: A Journey Through the Global Criminal Underworld. New York, Vintage books, 2009.

Gratteri, N. and A. Nicaso, Fratelli di sangue: storie, boss e affari della 'Ndrangheta, la mafia più potente del mondo. Milan, Oscar Mondadori, 2010.

Havocscope, Global black-market information. Available at: havocscope.com. Accessed 18 October 2018.

Hignett, K. Organized crime in East Central Europe: the Czech Republic, Hungary and Poland. Global Crime, Vol. 6, Nr. 1, 2004, 70-83.

Hobbs, D., Going down the glocal. The Howard Journal of Criminal Justice, volume 37(4), 1998, 1-19.

Hobbs, D. and G.A. Antonopoulos, How to research organized crime. In:

L. Paoli, The Oxford handbook of organized crime. Oxford, Oxford University Press, 2014.

Holm, H. and G. Sorensen, Introduction: what has changed? In: H. Holm and G. Sorensen, Whose world order: uneven globalisation and the end of the Cold War. Westview Press, Boulder Colorado, 1995.

IMF, Globalization: a brief overview. Issues Brief, May 2008.

Jong, de S. and K. Voskuil, Maffia paradijs. Amsterdam, Meulenhoff, 2017.

Kallenborn, H., Strijd tegen internationale misdadigers. Amsterdam, Keesing, 1953. 
KLPD, De 'Ndrangheta in Nederland. Aard, criminele activiteiten en werkwijze op Nederlandse bodem. Driebergen, Dienst Nationale Recherche, 2011.

Lampe, von, K., Organized crime. Analyzing illegal activities, criminal structures and extra-legal governance. Thousand Oaks CA, Sage, 2016.

Malone, M. and C. Malone-Rowe, Organized crime in Latin America. In: P. Reichel and J. Albanese, Handbook of Transnational Crime and Justice, $2^{\text {nd }}$ edition. Thousand Oaks, Sage, 2014, 471-482.

Massari, M., The Sacra Corona Unita: Origins, Characteristics, and Strategies. In: N. Serenata, The 'Ndrangheta and Sacra Corona Unita. The history, organization and operations of two unknown Mafia groups. Cham, Springer, 2014, 101-116.

Meyer, K. Perspectives on Multinational Enterprises in Emerging Economies. Journal of International Business Studies, Vol. 35, No. 4, 2004, 259-276.

Nationale politie, Verdachte van brandstichting Italiaans restaurant Nieuwstraat aangehouden. Press release, 16 September 2017.

Nationaal Rapporteur Mensenhandel en Seksueel Geweld tegen Kinderen, Mensenhandel in en uit beeld II. Cijfermatige rapportage 2008-2012. The Hague, Nationaal Rapporteur, 2014.

Paoli, L. The Italian Mafia. In: L. Paoli (ed.), The Oxford Handbook of Organized Crime. Oxford, Oxford University Press, 2014, 121-141.

Raine, L. and F. Cilluffo, (eds.), Global organized crime: the new empire of evil. Washington, DC, Center for Strategic and International Studies, 1994.

Reichel, P. and J. Albanese, Historical overview of transnational crime. In: P. Reichel and J. Albanese, Handbook of Transnational Crime and Justice, $2^{\text {nd }}$ Edition. Thousand Oaks, CA, Sage, 2014, 1-22.

Rovers, B. Corruption in the Rotterdam Sea Port: Iceberg or Fish Story? Paper presented at the $18^{\text {th }}$ Annual conference of the European Society of Criminology, Sarajevo, 29 August - 1 September 2018.

Sarno, F., Italian mafias in Europe: between perception and reality. A comparison of press articles in Spain, Germany and the Netherlands, Trends in Organized Crime, 17, 2014, 313-341.

Schelling, T., Economics and Criminal Enterprise, Public Interest, 7, 1965, 61-78. 
Sciarrone R., Ndrangheta: A rectular organization. In: N. Serenata, The 'Ndrangheta and Sacra Corona Unita. The history, organization and operations of two unknown Mafia groups. Cham, Springer, 2014, 8199.

Shelley, L., J. Picarelli and C. Corpora, Global Crime Inc. In: M. Cusimano, Beyond sovereignty: Issues for a global agenda. Florence KY, Thomson/Wadsworth, 2003.

Shelley, L., The globalization of crime. In: M. Natarajan, Introduction to International Criminal Justice. Boston, McGraw Hill, 2005, 3-10.

Shelley, L. and N. Hirst, Transnational threats: current and future trends. Paper presented at the Annual Security Review Conference, Vienna, 27-29 June 2017.

Sieber, U. and M. Bögel, Logistik der organisierten Kriminalität, Wiesbaden, Bundeskriminalamt, 1993.

Spapens, T., Interactie tussen criminaliteit en opsporing. Antwerp and Oxford, Intersentia, 2006.

Spapens, T., Georganiseerde misdaad en strafrechtelijke samenwerking in de Nederlandse grensgebieden. Antwerp and Oxford, Intersentia, 2008.

Spapens, T., M. Peters and D. van Daele, D., Administrative measures to prevent and tackle crime. The Hague, Eleven International Publishing, 2015.

Sterling. C., Octopus. The long reach of the international Sicilian mafia. New York, Simon and Schuster, 1990.

Tops, P., J. van Valkenhoef, E. van der Torre and L. van Spijk, L., The Netherlands and synthetic drugs: an inconvenient truth. The Hague, Eleven International Publishing, 2018.

Tremlett, G., The hunt for the Pink Panther gang, The Guardian, 23 August 2010.

Tweede Kamer, Kamerstukken II, Vergaderjaar 1995/96, 24 072, nr. 17, 1995.

Uhm, van, D., Uncovering the illegal wildlife trade, Utrecht, Phd thesis, 2016.

Ulrich, A., Das Engelsgesicht. Die Geschichte eines Mafia-Killers aus Deutschland. München and Hamburg, DVA and Spiegel Buchverlag, 2005.

UNODC, Results of a pilot survey of forty selected organized criminal groups in sixteen countries. Vienna, 2002. 
UNODC, The globalization of crime: a transnational organized crime threat assessment. Vienna, 2010.

UNODC, Global report on trafficking in persons 2016, Vienna, 2016.

Voskuil, K., Zuid-Amerikaanse bende pleegt golf van inbraken in ons land. $A D, 25$ May 2018.

Williams, P. Transnational Criminal Organisations and International Security, Survival, Vol. 36, No. 1, 1994, 96-113.

Williams, P., Transnational criminal networks. In: J. Arquilla and D. Ronfeldt (eds.), Networks and netwars: The future of terror, crime, and militancy. Washington DC, Rand Corporation, 2001.

Zwart, R., Comeback van een maffiabaas. Koninkrijksrelaties.nu, 27 July 2018. 